\title{
The role and function of trade usage in modern international sales law
}

Juana Coetzee*

\begin{abstract}
Trade usage reflects consistent and uniform business practices that are regularly followed in a particular trade. Trade usage has always played an important role in international sales as is evidenced by the lex mercatoria, an a-national system of law that flourished as autonomous law in medieval times but lost its influence after the introduction of the nation state. Today, the existence of the law merchant and the role and function of mercantile custom are clouded in controversy. Regardless of that, trade usage still fulfils a normative function in contracts of sale, so much so that contractual parties are bound by trade usage even in the absence of real knowledge. But what is the rationale for this situation? And what converts a mere consistent trade practice into a binding usage? These are some of the questions that this article seeks to answer. Whether the normative function of trade usage is restricted to contract interpretation and supplementation or whether trade usage can operate independent of party agreement is not clear. The traditional position is that trade usage operates as implied terms of the contract. Lately, however, less emphasis is placed on the requirement of knowledge. International and regional uniform law projects increasingly seem to afford trade usage binding force once a usage is widely followed in international transactions in a particular trade or industry. This article analyses the role and function of trade usage in modern day international sales law with reference to the position under selected national legal systems as well as under various international and regional instruments.
\end{abstract}

\section{Introduction}

Trade usage binds the parties to an international contract of sale, ${ }^{1}$ even if they are unaware of such usage at the time of contracting. This immediately raises

* Juana Coetzee, BA, LLB, LLM, LLD, Associate Professor, Department of Mercantile Law, Faculty of Law, University of Stellenbosch, South Africa. Email: jcoet@sun.ac.za. Parts of this article are based on research undertaken towards the author's doctoral dissertation, 'INCOTERMS as a Form of Standardisation in International Sales Law: An Analysis of the Interplay between Mercantile Custom and Substantive Law with Specific Reference to the Passing of Risk' LLD dissertation, University of Stellenbosch (2010).

1 Note that this article deals with so-called 'merchant sales' and does not cover consumer sales. Also note that the terms 'trade usage', 'trade practice', and 'trade custom' are used interchangeably, unless indicated otherwise.

(C) The Author (2015). Published by Oxford University Press on behalf of UNIDROIT. All rights reserved. For Permissions, please email journals.permissions@oup.com 
the question as to how the law binds someone to usages of which he had no knowledge, and why it would be prudent to do so. The question becomes even more relevant in a globalized world where there are an increasing number of newcomers to the trade. Is trade usage an unwritten law or perhaps a 'private' or 'specialized' language ${ }^{2}$ that merchants are presumed to know and that they, therefore, implicitly agree to as conditions or terms of the trade? Or are they bound to these usages by operation of law? Either way, what would be the rationale for the normative nature of trade usage or custom in international trade?

The normative function of trade custom is not a novel concept. It dates back to medieval times when international commercial transactions were regulated by the lex mercatoria, a body of law consisting of unwritten, but uniform, international mercantile customs and practices that were applied by judges in specialized merchant courts. However, the growth of nationalism ultimately led to a decline in the status of mercantile custom. ${ }^{3}$ Whether the law merchant still exists today as a supra-national law of international trade in some form or another is controversial. ${ }^{4}$ Although some individuals support the notion of autonomous law based on mercantile customs and other general principles of trade that transcend physical and legal boundaries, ${ }^{5}$ others are of the opinion that custom can only operate in very specific circumstances, such as through party agreement contained in national law, where model laws and international conventions, once ratified or

2 See Lisa Bernstein, 'Trade Usage in the Courts: The Flawed Conceptual and Evidentiary Basis of Article 2's Incorporation Strategy' University of Chicago Coase-Sandor Institute for Law and Economics Research Paper No 669, University of Chicago Public Law Working Paper No 452, 42 <http://www.law.uchicago.edu/files/file/669-452-lb-trade-2.pdf> and < $>$ ttp://ssrn.com/ abstract $=236653>$ accessed 11 April 2015; Lisa Bernstein 'Merchant Law in a Modern Economy' University of Chicago Coase-Sandor Institute for Law and Economics Research Paper No 639, 2d Series, 19 <http://ssrn.com/abstract=2242490> accessed 11 April 2015; Elizabeth Warren, 'Trade Usage and Parties in the Trade: An Economic Rationale for an Inflexible Rule' (1980-1) 42 University of Pittsburgh Law Review 515, 542.

3 JH Dalhuisen, 'Custom and Its Revival in Transnational Private Law' (2008) 18 Duke Journal of Comparative and International Law 339, 339-43; Jürgen Basedow, 'The State's Private Law and the Economy: Commercial Law as an Amalgam of Public and Private Rule-Making' (2008) 56 American Journal of Comparative Law 703, 703-6; FK Juenger, 'The Lex Mercatoria and Private International Law’ (2000) Uniform Law Review 171, 173; Clive M Schmitthoff, International Trade Usages (Institute of International Business Law and Practice 1987) paras 64-74; Stephen Bainbridge, 'Trade Usage in International Sales of Goods: An Analysis of the 1964 and 1980 Sales Conventions' (1984) 24 Virginia Journal of International Law 619, 624-8.

4 P Le Goff, 'Global Law: A Legal Phenomenon Emerging from the Process of Globalisation' 14 (2007) Indiana Journal of Global Legal Studies 119, 125-6. Whether it ever existed as an autonomous law is also in dispute. See Ralf Michaels, 'The True Lex Mercatoria: Law beyond the State' (2007) 14 Indiana Journal of Global Legal Studies 447, 453.

5 According to the autonomist approach, the lex mercatoria exists independently of any national law and consists of merchant practices, usages, and customs supplemented by the general principles of law that are recognized by merchants, such as those contained in the International Institute for the Unification of Private Law (UNIDroIT) Principles on International Commercial Contracts, restatements of the law, standardized contracts, and conditions of trade. See HJ Berman and C Kaufman, 'The Law of International Commercial Transactions (Lex Mercatoria)' (1978) 19 Harvard International Law Journal 221, 272-7; Dalhuisen (n 3) 348; and, in general, Klaus Peter Berger, The Creeping Codification of the New Lex Mercatoria (2nd revised edn, Kluwer Law International 2010). 
acceded to, or where international codifications of customs and practices are contractually incorporated. ${ }^{6}$

Even outside the lex mercatoria debate, the role and function of unwritten and uncodified trade usage in international sales law generate differences in opinion. While adherents of its rule-making role regard mercantile custom as the basis of modern international commercial law, ${ }^{7}$ courts have been criticized for acting contrary to the principles of party autonomy or economic efficiency when incorporating trade usages in the absence of party agreement. ${ }^{8}$ The legislative history of the United Nations Convention on Contracts for the International Sale of Goods (CISG) $)^{9}$ illustrates the controversy that surrounds the normative function of trade usage. During its drafting stages, the role of trade usage was one of the so-called 'political issues' that generated considerable debate. The substitution of substantive law for trade usage was viewed as neo-colonialist or imperialistic. Especially developing and socialist countries were concerned that the Convention would hold their traders bound to usages of the developed world of which they had little or no knowledge. ${ }^{10}$ A compromise was reached in the form of Article 9(2) of the CISG, which provides that trade usage will govern the parties' contractual relationship once the usage is internationally known and regularly observed by parties in that particular trade and the parties knew or ought to have known the usage. This provision seeks to combine the subjective and objective approaches to trade usage.

One scholar claims that trade usage has reached its expiry date and in due time will be overtaken by trade practices that individual contractual parties develop between themselves. The premise for this view is that trade usage can only thrive in closed business circles where the usage is known to everyone. In a globalized environment where commercial interaction is not limited to closed groups, it is difficult to establish and prove its content, which means that trade usage will

6 For the positivist approach, see Abdul FM Maniruzzaman, 'The Lex Mercatoria and International Contracts: A Challenge for International Commercial Arbitration' (1999) 14 American University International Law Review 657, 671-2; Clive M Schmitthoff, 'The Unification of the Law of International Trade' in J Cheng (ed), Clive M Schmitthoff's Select Essays on International Trade Law (Marthinus Nijhoff 1988) 170, 171-2; Schmitthoff (n 3) paras 64-74.

7 Berman and Kaufman (n 5) 272-3; Aleksander Goldštajn, 'Usages of Trade and Other Autonomous Rules of International Trade According to the UN (1980) Sales Convention' in Petar Šarčević and Paul Volken (eds), International Sale of Goods: Dubrovnik Lectures (Oceana Publications 1986) 55, 56; Clayton P Gillette, 'Harmony and Stasis in Trade Usage for International Sales' (1999) 39 Virginia Journal of International Law 707, 710.

8 Ch Pamboukis, 'The Concept and Function of Usages in the United Nations Convention on the International Sale of Goods' (2005-06) 25 Journal of Law and Commerce 107, 107; Claire Cutler, Private Power and Global Authority: Transnational Merchant Law in the Global Political Economy (OUP 2003); Bernstein, 'Trade Usage' (n 2).

9 UN Convention on Contracts for the International Sale of Goods 19 ILM 668 (1980) [CISG].

10 Ingeborg H Schwenzer, Pascal Hachem and Christopher Kee, Global Sales and Contract Law (OUP 2012) para 27.40; John O Honnold, Uniform Law for International Sales (4th edn by Harry M Flechtner, Wolters Kluwer 2009) para 118; Michael Joachim Bonell, 'The CISG, European Contract Law and the Development of a World Contract Law' (2008) 56 American Journal of Comparative Law 1, 2; Bainbridge (n 3) 633-44. 
eventually lose its relevance due to a lack of certainty. ${ }^{11}$ The inherent uncertainty of uncodified practices makes it very difficult to invoke trade usage satisfactorily, which is a serious drawback for its operation. Often trade usage is understood, and thus interpreted, differently depending on the sphere of application, the geographical location of the usage or even the location of the court that has to apply such usage. The flexible and dynamic nature of trade usage, which enables it to evolve as trade conditions develop, adds to this uncertainty. Apart from exceptional cases where the courts can take judicial notice of a particular trade usage, it can be extremely problematic to prove its existence and content. ${ }^{12}$ This might be slightly different in the context of arbitration where arbitrators are better acquainted with usages of the trade than judges in national courts. However, every so often, expert evidence on the content of trade usage yields contradictory results. Consequently, research conducted in the USA has shown that traders prefer standard form contracts of trade associations to the uncertainty of unwritten customs and usages. $^{13}$

Although lack of certainty on the content of trade usage, and the problems connected to proving its content, can impede the role and function of trade usage, publicly accessible databases, industry guidelines, codes of conduct, and standardized trade practices are already providing greater accessibility to the content of trade usage than in the past. ${ }^{14}$ Trades and industries that organize themselves in business associations not only standardize but also often generate commercial usage through standard term contracts, such as, for example, the Grain and Feed Trade Association contracts, ${ }^{15}$ the International Federation of Consulting Engineers contracts, ${ }^{16}$ the GENCON standard contracts for charter parties, or the International Swaps and Derivatives Agreement Master Agreement. ${ }^{17}$ Furthermore, the need to resort to international trade usage has in many instances been rendered unnecessary through contractual agreement on

11 Filip De Ly, 'Sources of International Sales Law: An Eclectic Model' (2005-06) 25(1) Journal of Law and Commerce 1, 5.

12 According to Bernstein, 'Trade Usage' (n 2) 31, traders hardly use objective evidence or expert witnesses to prove the content of trade usage in court. Consequently, its application very often amounts to a legal fiction. See also Gillette (n 7) 711, 716.

13 John Linarelli, 'The Economics of Uniform Laws and Uniform Lawmaking' (2003) 48 Wayne Law Review 1387, 1439-40; Lisa Bernstein, 'Merchant Law in a Merchant Court: Rethinking the Code's Search for Immanent Business Norms' (1996) 144 University of Pennsylvania Law Review 1765; Bernstein, 'Trade Usage' (n 2) 41-2, 48-9.

14 Vanessa Mak, 'According to Custom...? The Role of "Trade Usage" in the Proposed Common European Sales Law (CESL), Tilburg Law School Legal Studies Research Paper Series No 02/2014, 3-15 < http://ssrn.com/abstract=2364427> accessed 11 April 2015.

15 The so-called GAFTA contracts. Other examples are the standard contracts of the Sugar Association of London or the Waren-Verein der Hamburger Börse e.V.

16 The co-called FIDIC contracts. Other examples are the general conditions of trade formulated by the United Nations Economic Commission for Europe, eg the General Conditions for the Supply of Plant and Machinery for Export 1953, or, in the engineering industry, the General Conditions for the Supply of Mechanical, Electrical and Electronic Products, which was developed by the European Industries Engineering Organization (the so-called ORGALIME contracts).

17 The so-called ISDA Agreement. The International Chamber of Commerce Model International Contract of Sale provides another example. 
standardized trade usages such as the International Chamber of Commerce (ICC) Uniform Commercial Practice for Documentary Credits (UCP), the ICC Uniform Rules for Demand Guarantees, and the ICC Incoterms or the incorporation of trade usage into national statutes and international conventions. ${ }^{18}$ It would, therefore, not be implausible to argue that the opportunities provided by a globalized world would facilitate, rather than inhibit, notions of self-regulation and autonomous law based on mercantile customs and usages. ${ }^{19}$

Despite divergent opinions, it is clear that mercantile customs and usages continue to play an important role in international trade, ${ }^{20}$ so much so that the business community confers trade usage with a status equivalent to that of law, and many business relationships rely solely on trade usage as a means of regulation. $^{21}$ Moreover, comparative analyses of domestic legal systems and instruments of international sales law show that trade usage is applied both as a gap-filler and interpretive tool. Unwritten trade usage fulfils an important role in the context of international sales, such as in the formation of contracts to establish, for example, whether contracts are concluded through silence or conduct following on the receipt of a letter of conformation containing standard terms that are different from the parties' prior negotiations or agreement. ${ }^{22}$ Usage can also play a role in the determination of price and the possibility of revising the price after contract conclusion. One arbitral tribunal held that, in the trade of minerals, revision of price is a usage regularly observed by parties to contracts of that type. ${ }^{23}$ In another case, a court held that the bill of exchange given by the buyer had validly modified the contract by virtue of Article 29(1) of the CISG to the effect that the date of payment of the purchase price was postponed until the date when the bill of exchange was due. ${ }^{24}$ In reaching this conclusion, the court took into account the existence of an international trade usage to this effect and its relevance pursuant to Article 9(2) of the Convention. Trade usage is furthermore used in determining the reasonable time within which the buyer has to examine the goods and inform the seller of any non-conformity as required by Articles 38 and 39 of the CISG. Another court stated that a trade usage existed in the particular trade concerned, according to which the buyer had to give the seller an

18 Such as, eg, the Hague and Hague-Visby Rules, which deal with bills of lading.

19 Marlene Wethmar-Lemmer, 'The Development of the Modern Lex Mercatoria: A Historical Perspective' (2005) 11 Fundamina 183, 199.

20 United Nations, 'Unification of the Law of International Trade' Note by the Secretariat Official Records of the General Assembly 20th Session, Doc A/C.6/L.572 (1968) para 15.

21 Leonardo Graffi, 'Remarks on Trade Usages and Business Practices in International Sales Law' (2011) 29 Journal of Law and Commerce 273, 273.

22 Graffi (n 21) 291-4; Germany, 5 July 1995, Appellate Court Frankfurt (Chocolate products case) <http://cisgw3.law.pace.edu/cases/950705g1.html> accessed 11 April 2015; Switzerland, 21 December 1992, Civil Court Basel (Textiles case) < http//cisgw3.law.pace.edu/cases/9211221s1. html> accessed 11 April 2015.

23 International Chamber of Commerce (ICC) Arbitration, Case No 8324 of 1995 (Magnesium case) <http://cisgw3.law.pace.edu/cases/958324i1.html> accessed 11 April 2015.

24 Germany, 26 September 1990, District Court Hamburg (Textiles case) <http://cisgw3.law.pace. edu/cases/900926gl.html> accessed 11 April 2015. 
opportunity to be present while checking the goods. ${ }^{25}$ In similar vein, payment of interest has been regarded as an accepted usage of international trade. ${ }^{26}$

This article sets out to form an opinion on the role and function of mercantile custom in modern international sales law. It commences by establishing a working definition for the concept of trade usage. This is followed by an investigation into the rationale for the normative character of usage. In order for trade usage to enjoy normative force, it has to meet stringent criteria set by the applicable law of the contract. The bulk of the article comprises a comparative analysis on the manner that trade usage is applied in international sales law. The focus in this part is to establish whether trade usage can operate independently of party agreement by operation of law or whether its application is limited to that of an interpretive tool or gap-filler based on implied agreement. The article is concluded with a summary of findings on the role and function of trade usage in international sales law of the twenty-first century.

\section{Defining trade custom and usage}

Comparative analysis shows that it is no easy task to define trade custom and usage. Custom is a vague concept that, on the one hand, is used as a synonym for trade usage or practice, while, on the other, they are used in different contexts and meanings. ${ }^{27}$ For the purposes of this article, these terms are used interchangeably unless otherwise indicated. A number of legal systems apply trade custom and usage without attempting to define it. ${ }^{28}$ German law, for example, provides for customs and trade usages in section 346 of the Handelsgesetzbuch (HBG) simply by stating:

Unter Kaufleuten ist in Ansehung der Bedeutung und Wirkung von Handlungen und Unterlassungen auf die im Handelsverkehr geltended Gewohnheiten und Gebräuche Rücksicht zu nehmen.

The same holds true for international instruments used in the regulation of international trade matters such as the 1985 UNCITRAL Model Law on International Commercial Arbitration (as amended in 2006). ${ }^{29}$ Article 28(4) of the Model Law reads: 'In all cases, the arbitral tribunal shall decide in accordance with the terms of the contract and shall take into account the usages of the trade applicable to the

25 Finland, 29 January 1998, Helsinki Court of Appeal (Steel plates case) < http://cisgw3.law.pace. edu/cases/980129f5.html> accessed 11 April 2015.

26 Gillette (n 7) 715.

27 Roy M Goode, 'Usage and Its Reception in Transnational Commercial Law' (1997) 46(1) International and Comparative Law Quarterly 1, n 20, refers to the 'linguistic ambiguity' of usage and custom. See also Jan Dalhuisen, Dalhuisen on Transnational Comparative, Commercial, Financial and Trade Law, Vol 1: Introduction - The New Lex Mercatoria and the Sources (4th edn, Hart Publishing 2010) 155, n 326, who points out that, because of its 'fluid nature' custom can over time move from an contractual implied term to objective law.

28 Schmitthoff (n 3) para 9.

29 United Nations Commission on International Trade Law (UNCITRAL), Model Law on International Commercial Arbitration 1985 (as amended 2006) <http://www.uncitral. org/uncitral/en/uncitral_texts/arbitration/1985Model_arbitration.html> accessed 30 June 2015. 
transaction.' American law, on the other hand, not only recognizes but also defines trade usage. Section 1-303(c) of the 2001 Uniform Commercial Code (UCC) provides that:

[a] usage of trade is any practice or method of dealing having such regularity of observance in a place, vocation or trade as to justify an expectation that it will be observed with respect to the transaction in question. ${ }^{30}$

Trade practice or course of dealing, ${ }^{31}$ in the restricted sense of the term, consists of a practice that contract parties have established between themselves over a period of time. It would depend on the particular facts of the case whether a course of dealing will be recognized by law. The number of times and the frequency with which the practice has been applied in the past will play an important role here. $^{32}$

Despite a lack of clear definition, it can be concluded that trade usage constitutes unwritten practices or patterns of behaviour that have originated in a particular trade or industry, have been in existence for a long time, are well known and are widely and regularly observed by merchants who engage in that trade or industry. Knowledge of the practice or usage is not always required. If you engage in a particular trade where a usage is regularly observed, the expectation of knowledge will often suffice and, thus, be protected. But what would be the rationale for incorporating an unwritten trade usage into a contract even where the parties are unaware of its existence?

\section{Rationale for the normative character of trade usage}

In most cases, the origin of a trade usage can be traced back to an initial agreement between two contractual parties. Over the course of a number of transactions between them where they agree on the same contractual obligations that are performed in the same manner, the one party will expect the other to perform in accordance with their original contract without saying. By that time, a practice would have developed between them, and both of them will be bound thereto, so that one party's failure to do so would entitle the other party to legal relief. The legal force of such a practice is based on implied agreement and, thus, obtained from the principle of party autonomy.

Once the practice is noticed by others engaged in the trade or industry and recognized as an efficient commercial practice they might also decide to follow suit. Commercial parties tend to gravitate towards the most optimal business

30 American Restatement (Second) of the Law of Contracts (1981) s 222 defines trade usage in virtually the same language.

31 Uniform Commercial Code (UCC) (2001) s 1-303(b) defines a course of dealing as 'a sequence of conduct concerning previous transactions between the parties to a particular transaction that is fairly to be regarded as establishing a common basis of understanding for interpreting their expressions and conduct.'

32 Schwenzer, Hachem and Kee (n 10) para 27.12-5. 
practices to increase the efficiency of their transactions and eventually their profit. When such a practice becomes well known to the extent that it is regularly and consistently observed in a particular trade or industry by those engaged in that trade, it becomes a trade usage. ${ }^{33}$ Once it is a usage of the trade, everyone active in that trade is expected to know and follow it.

One of the reasons for protecting such an expectation lies in the promotion of economic efficiency. ${ }^{34}$ As there is no longer any need to negotiate the terms contained by the usage, time and money are saved. In the commercial context, parties often deliberately fail to provide for all contingencies of a transaction. This would happen where the costs of contracting are excessive to the extent that they outweigh all of the benefits or if the magnitude or probability of a contingency is sufficiently low. ${ }^{35}$ The gaps in incomplete contracts are either filled by the applicable law or by interpreting the terms of the contract. Default law substitutes the need for explicit agreement as it normally reflects the rule that the majority of parties would have wanted. ${ }^{36}$ Trade usage fulfils a similar function. As they consist of homogeneous, harmonized, and efficient practices that most contractual parties would have agreed on if they had the opportunity to do so, trade usages operate as default gap-fillers. ${ }^{37}$ In this way, transaction costs are reduced by supplanting the negotiation and drafting costs of explicit contractual clauses. ${ }^{38}$

Courts mostly recognize trade usage on the basis of implied agreement. An objective test is applied, namely that a reasonable person who is active in that particular trade would have known the practice and would have concluded the contract with the intention that the usage should form part of their agreement. Trade usages that are well known internationally and are regularly observed in the trade are thus implied as part of the contractual agreement. Subjective knowledge would generally be irrelevant as the emphasis is placed on protecting the expectation of the other party to that contract.

However, whether the expectation of the other contractual party is to be protected by the law merely on grounds of general observance and repetitive use of the practice in the trade is an issue that needs to be investigated a little closer.

33 Gillette (n 7) 708, 721. See also Dalhuisen (n 27) 159.

34 Gillette (n 7) 709; Warren (n 2) 543-4

35 Richard A Posner, Economic Analysis of the Law (6th edn, Aspen Publishers 2003) 96; Alan Schwartz and Joel Watson, 'The Law and Economics of Costly Contracting' (2004) 20 Journal of Law Economics and Organization 2, 2-3; Linarelli (n 13) 1401-2.

36 See Ian Ayres and Robert Gertner, 'Filling Gaps in Incomplete Contracts: An Economic Theory of Default Rules' (1987) 99 Yale Law Journal 87, 89-90; 'Unification and Certainty: The United Nations Convention on Contracts for the International Sale of Goods' Note by Law Student (1979) 65 Harvard Law Review 557, 558-9; Mitchell Stocks, 'Risk of Loss under the Uniform Commercial Code and the United Nations Convention on Contracts for the International Sale of Goods: A Comparative Analysis and Proposed Revision of UCC Sections 2-509 and 2-510' (1993) 87 Northwestern University Law Review 1415, 1445-6.

37 Gillette (n 7) 707-8.

38 See Bainbridge (n 3 ) 650-1 on the cost benefits of trade usage. See also Warren (n 2) 541ff. Contra, Bernstein, 'Trade Usage' (n 2), who is of the opinion that the interpretive costs of trade usage could outweigh the costs of providing for all contingencies contractually. See also Mak (n 14), who warns against the costs of usages that are not widely or internationally known. 
Practices can be followed on a regular basis in a particular trade 'as a matter of habit, courtesy or convenience or simply a desire to accommodate one's business counterparty voluntarily where this is not detrimental to one's own interests. ${ }^{39}$ Would that be enough reason to protect the expectation of the other party and, thus, to confer legal effect on such a practice? In the context of international customary law, as recognized by public international law, a consistent practice (usus) should be accompanied by a belief that the practice is legally binding (the so-called opinio iuris necessitates) before a custom would enjoy any normative force. $^{40}$

In General Reinsurance Corp v Forsakringsaktiebolaget Fennia Patria, ${ }^{41}$ Lord Justice Slade remarked that there is a world of difference between observing a practice as a matter of grace and a practice that is observed as a legal obligation. A legal obligation would imply that the other party to the contract has a legally binding right to demand observation of the usage, while, in cases where there is no obligation, the other party will usually have no recourse. ${ }^{42}$ This dictum was considered and applied by Justice Staughton in Libyan Arab Foreign Bank v Bankers Trust $\mathrm{Co}^{43}$ In this matter, the court had to decide whether the defendants had a right to demand that payment should be made through a US clearing system. The plaintiffs in this case held a Eurodollar deposit with an American bank. Subsequent to a freeze on Libyan assets imposed by the president of the USA, they sought payment of the deposit in cash or any other manner that did not involve having to clear the payment through a US clearing system. The defendants argued that it was a trade usage of the Eurodollar deposit market that deposits could only be withdrawn through the clearing system of the currency in which the account was denominated, which was US dollars and, therefore, would mean that the presidential decree had to be applied and the funds accordingly frozen. The defendant's expert witness, however, testified that the practice was merely followed as a matter of commercial convenience and not from a sense of legal obligation, which led the court to conclude there was no binding practice or usage to that effect. Consequently, the Libyan party was entitled to withdraw the London deposit of nearly US $\$ 300$ million in cash.

Although usage is of itself not legally binding under English law and derives its force solely from the express or implied consent of the contractual parties, it seems that the courts only confer legal effect to a practice if its users consider it to be a binding rule. ${ }^{44}$ A similar requirement has been stated in Italian law, ${ }^{45}$ the

39 Goode (n 27) 10.

40 According to Goode (n 27) 9, there is a direct parallel between the sources of international customary law and that of international mercantile law. The American Restatement (Revised), Foreign Relations Law of the United States, s 102, for instance, also requires a 'sense of legal obligation'.

41 [1983] QB 856, 874.

42 Except perhaps on the grounds of good faith.

431989 QB 728.

44 Halsbury's Laws of England, vol 32 (5th edn, Lexis Nexis 2012) para 50.

45 Graffi (n 21) 276. 
law of the Philippines ${ }^{46}$ the civil code of Estonia, ${ }^{47}$ and has, for instance, also been mentioned by the Supreme Court of Germany. ${ }^{48}$ On the other hand, the US Uniform Commercial Code (UCC) ${ }^{49}$ and Chech law, for example,${ }^{50}$ merely require regular observance. Article 9(2) of the CISG also makes no reference to such a requirement. However, it would be logical to assume that not all practices that are regularly observed in the trade will be recognized by law. To convert a mere practice into a binding usage, there must be some perception of obligation amongst its users, even if that is not a legal obligation per se. ${ }^{51}$ What is problematic, though, is that such a requirement is in essence based on a paradoxical or circular argument. It presupposes that there is an existing legal duty that, if correct, would mean that there is no need for such a belief or perception as the usage would be law already. On the other hand, if the belief would be wrong, it would convert non-law into law through error. ${ }^{52}$

How would one then rationalize the mercantile community's sense of obligation to observe particular practices on a regular basis? This is perhaps best understood in the context of an environment that is essentially shaped by merchants for merchants in line with commercial convenience and efficiency. Whether the business community can make their own law is a jurisprudential question that, due to its wide scope and complexity, cannot be addressed in any detail in this article. This question essentially depends on what is considered to be the sources of law. ${ }^{53}$ At the same time, it is linked to the debate on an autonomous international mercantile legal order, or lex mercatoria, which businessmen maintain among themselves. Such an order would exist between business professionals, either in an organized form as in the case of trade associations or in a more informal form. Either way, trade usage and custom would form the basis of their regulatory framework. ${ }^{54} \mathrm{~A}$ sense of obligation to observe the practices of the trade would therefore not necessarily mean a sense of 'legal' obligation as understood by national law but, rather, a sense of obligation to keep to the 'rules of the trade' - thus, an obligation towards the mercantile order that regulates and facilitates international trade. It is common knowledge that the mercantile community prefers dispute resolution through internal adjudication bodies and arbitral tribunals that are more inclined to make use of customs and usages as sources of law when they are called upon to resolve mercantile disputes. ${ }^{55}$

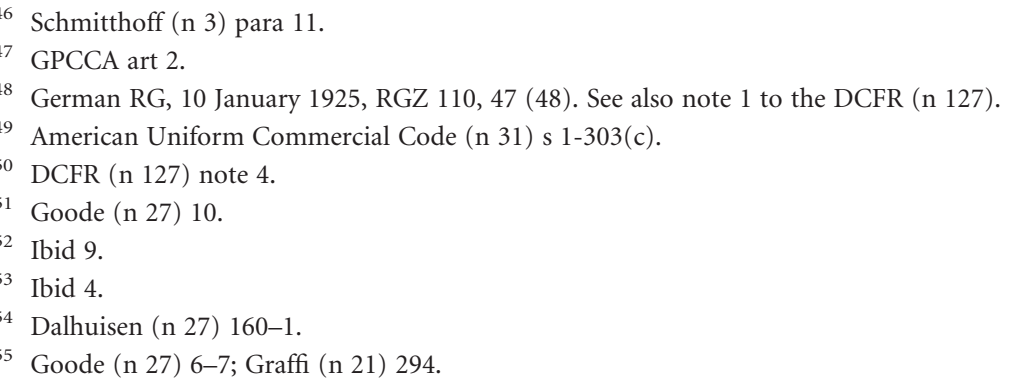


Roy Goode attempts to capture the notion of obligation in this context by requiring that the usage 'must be one which is considered by the relevant mercantile community to bear on the making, proof, interpretation, performance or enforcement of the parties' commercial engagements towards each other. ${ }^{56}$ If you engage in a particular trade as a professional businessman, you are presumed to perform your contractual duties with a reasonable degree of skill and care. At the same time, it is presumed that you will acquaint yourself with the usages of the trade and observe the same. A presumption of professional competence could provide a further rationale for why the law denotes legal effect to trade usages that are regularly observed by the mercantile community in a particular trade from a sense of obligation, even when one or both of the parties to the contract has no real knowledge of the practice but ought to have been aware of it. $^{57}$

Whether regular observance of a consistent practice coupled with a sense of obligation to observe such usage will suffice as a basis for the normative function of trade usage or whether it must first receive judicial, arbitral, or legislative recognition is another issue that requires mention. In essence, there are two arguments. According to the first argument, usage exists independent of the sanction of a court, arbitral tribunal, or legislative enactment. The court's role is a purely declaratory one. Its ruling would therefore not constitute the source of the law, but the usage itself would be the source. ${ }^{58}$ The second argument states that usage is dependent on recognition by one of these institutions for its existence. In the absence of any statutory codification of, or express agreement on, trade usage, it would mean that the normative force of trade usage is dependent on satisfying certain criteria that are set by the law and that the usage does not have any existence of its own. ${ }^{59}$

The first-mentioned argument would be preferable, especially if the dynamic nature of trade usage is taken into consideration. Usage is a factual issue that exists independent of the law and receives its legitimacy from observance by the mercantile community itself. Once this observance becomes entrenched, the courts and tribunals merely recognize it as the source of law that it already is. However, most legal systems would only recognize its normative force if it satisfies certain criteria set by the applicable law. If these criteria are met, it would simply confirm that the usage already exists and, thus, would not 'create' the usage. But what would constitute trade usage? It is necessary that the criteria set by different legal systems should be investigated in more detail.

56 Goode (n 27) 10.

57 See Trans-lex Principles Title: I.2.2: Trade Usages <http://www.trans-lex.org/903000> accessed 11 April 2015. See, however, Schmitthoff (n 3) paras 15-16, who refers to the country reports of Switzerland and Sweden that indicated that trade usages unknown to one of the parties will not form part of their contract.

58 Goode (n 27) 11.

59 Ibid 10-11. 


\section{Requirements for the operation of trade custom and usage}

\section{General}

Although there might be slight differences between trade practices, usages, and customs, their common trait is that parties to a contract are bound by them once they are observed within a particular trade or industry. Whether the parties have to agree on the practice, at least tacitly or impliedly, or whether it simply has to be followed with such frequency and for such duration of time that it creates an expectation that this conduct will be continued, irrespective of whether a party is aware of the practice, differs from one system to the next. There is no hard-andfast rule on the frequency or duration of time that the trade usage or practice is to be followed before it will obtain binding quality. Generally, it is to be determined on a case-by-case basis, but the practice should be conducted repetitively over a period of time. Usages should also be widely known and observed in the trade or industry. ${ }^{60}$ Most legal systems require that the trade usage should be reasonable and consistent with the mandatory law and that it will be superseded by the agreement of the parties. ${ }^{61}$ Whether usage only functions as an implied term of the contract based on agreement or whether it can be implied by law will ultimately depend on the governing law of the contract and the extent to which it recognizes the autonomous normative nature of trade usage. Ultimately, the normative force of trade usage depends on satisfying certain criteria that vary from jurisdiction to jurisdiction. In order for it to be implied by law independent of party agreement or knowledge, national law will apply the requirements for its application more stringently than would be the case with implied contractual terms. ${ }^{62}$

The analysis will commence with a discussion of the legal position on trade usage in a number of legal systems. The traditional division between common law and civil law systems provides the basis for this discussion-hence, the focus on English, American, and German law, supplemented by South African law as a mixed legal system. The discussion of national law will be followed by an analysis of various uniform law projects aimed at harmonizing the law applicable to crossborder commercial contracts.

\section{National law}

\section{A. Common law}

English law differentiates between custom as a source of law and trade usage as an implied term of the contract. ${ }^{63}$ It is required that custom should have immemorial existence, while that is not required of a usage. Second, custom should be

\footnotetext{
60 Schwenzer, Hachem and Kee (n 10) para 27.32-5.

61 Ibid paras 27.28, 27.43-4.

62 Goode (n 27) 33-34; Schwenzer, Hachem and Kee (n 10) para 27.36-8.

63 Halsbury's Laws (n 44) para 51.
} 
confined to a limited locality, whereas that is not the case for usage. Third, while trade usage should conform to the positive law, custom is by nature inconsistent with the general law of the realm. ${ }^{64}$ Trade usage, furthermore, must consist of certain, reasonable, and uniform practices that are notorious and, thus, well known in the trade and are consistent with the terms of the contract. It is also required that the parties must recognize the binding nature of the usage. ${ }^{65}$

In English law, apart from being an interpretive tool, usages have mostly been relegated to an implied term. ${ }^{66}$ Since knowledge of the usage is required, either express or implied, trade usage does not enjoy any normative force independent of party agreement. ${ }^{67}$ Only local custom may have the force of law independent from the contract if it meets stringent criteria, namely that of an immemorial and continued existence, reasonableness, and certainty. ${ }^{68}$ Despite an increasing tendency to use these terms interchangeably, the essential difference in legal nature between customs and usages still continues to exist in English law. ${ }^{69}$

Although American law recognizes custom as a source of law, the requirements for custom as laid down in English law are rarely applied in the USA. ${ }^{70}$ The English test for custom, namely that it should be 'ancient or immemorial' or that the usage should be 'universal' or 'notorious', has been completely abandoned. ${ }^{71}$ Therefore, there is no longer a clear difference between custom and usage in American law, and the courts tend to use these terms interchangeably. ${ }^{72}$

Under both the UCC and the common law, custom, trade usages, and practices may be used for the interpretation and supplementation of contracts. ${ }^{73}$ American law requires that the trade custom or usage must be definite and in use for a considerable length of time to the extent that anyone engaged in that trade may reasonably be expected to know it. ${ }^{74}$ As for commercial contracts, Article

64 Ibid paras 1, 5. See also, on English customary law in general, EK Braybrooke, 'Custom as a Source of English Law' (1951) 50 Michigan Law Review 71.

65 Roy Goode, Goode on Commercial Law, edited by Ewan McKendrick (4th revised edn, Penguin Books 2010) 14, 97; Halsbury's Laws (n 44) paras 50, 56-61.

66 Halsbury's Laws (n 44) paras 51, 53; Goode (n 65) 14, 97; Dalhuisen (n 3) 339, n 7, 358; Basedow (n 3 ) 706. However, see also Dalhuisen (n 27) 157, who is of the opinion that common law judges have shown greater dynamism in the development of customary law in commercial cases than in non-commercial cases.

67 Goode (n 65) 97, n 156.

68 Halsbury's Laws (n 44) paras 1, 6-19, 51.

69 Goode (n 65) 13, n 57; 97, n 154; Halsbury's Laws (n 44) paras 1, 51.

70 'Unification and Certainty' (n 36) 1204; Williston on Contracts, vol 12 (4th edn, West Group 1999) para 34:2.

71 Williston on Contracts (n 70) paras 34:12, 34:17; Threadgill v Peabody Coal Co 34 Colo App 203, 526 P 2d 676 (1974); Warren (n 2) 521-2.

72 Williston on Contracts ( $\mathrm{n} 70$ ) para 34:2; Oppenheimer Bros Inc v Joyce \& Co 20 Ill App 2d 34, 154 NE 2d 856.

73 UCC (n 31) ss 1-103, 1-303 (d). See also Restatement (Second) of Contracts (n 30) s 222(3); Corbin on Contracts, vol 5 (Lexis Nexis Publishing 1998) paras 24:10, 24:13; E Allan Farnsworth, Contracts (3rd edn, Aspen Law and Business 1999) 484; Williston on Contracts (n 70) paras 34:1, 34:3.

74 Corbin on Contracts (n 73) para 24:15; Farnsworth (n 73) 485-6. See Williston on Contracts (n 70) paras $34: 1,34: 17$, who points out that the time can be brief as long as the parties can be expected to know the usage. 
1-303(d) of the UCC states that if it is a usage of the trade in the industry or trade 'in which they are engaged or of which they are or should be aware', trade usage can be used to ascertain the meaning of the parties' agreement, give particular meaning to specific terms and supplement or qualify the terms of the agreement. This means that parties will be bound to usages that are observed in the trade or industry in which they are active irrespective of knowledge or, if they are not active in the trade, that they could still be held bound to such usages on the basis of presumed or constructive knowledge derived from the circumstances of the case. $^{75}$

\section{B. Civil law}

Civil law countries mostly deal with usage as an interpretative tool or as an implied term of the contract. ${ }^{76}$ In German law, the Civil Code in sections 157 and 242 of the BGB directs the use of good faith and fair dealing together with trade usage (Verkehrssitte) to interpret the terms of a contract. ${ }^{77}$ As for commercial contracts, the Commercial Code (section 346 of the HGB) states that between merchants, regard is to be had to the customs and usages of that trade in determining the meaning and effect of the parties' conduct and statements. ${ }^{78}$ Trade usage as referred to in section 346 of the HGB represents a category of usage that is known to a whole sector of the economy and is practised by traders voluntarily and in a uniform way (so-called Handelsbräuche). Trade usage should be distinguished from trade practices that exist between individual parties (Handelsübungen). The notions of Gebräuchen and Gewohnheiten are, however, often used as synonyms and are equated to Handelsbrauch. ${ }^{79}$ Usage of this kind is binding on the parties even if they do not know it, and it takes precedence over dispositive, but not over mandatory, provisions of statutory law. It would seem that in German law its operation is primarily still based on an

75 Williston on Contracts (n 70) paras 34:3, 34:16. According to Warren (n 2) 523, it would seem that two separate standards exist; in circumstances where you ought to know the usage, constructive knowledge will form the basis of its application but if you are 'in the trade' you will be bound by the usage as a normative rule of law independent of party agreement or knowledge. Schwenzer, Hachem and Kee (n 10) para 27.29 refer to this as the 'quasi-statutory nature of usage'. The rationale for the inflexible standard would lie in the reduction of transaction costs. By holding parties to a trade usage where both of them are in the trade, merchant expectations are protected. Learning costs experienced by a newcomer to the trade would indirectly force him to acquaint himself with these usages in order to force transaction costs down again. In practice, the courts, however, do not apply the inflexible normative standard applicable to those in the trade consistently, and they mostly rely on constructive knowledge, even in those situations where both parties are active in the trade. See Warren (n 2) 533-4, 541ff.

76 See Basedow (n 3 ) 706 for the position in French and German laws.

77 Dalhuisen (n 3) 359; J Köndgen and G Borges, 'Commercial Law' in M Reimann and J Zekoll (eds), Introduction to German Law (2nd edn, Kluwer Law International 2005) 121, 124-5.

78 See Staub/Handelsgesetzbuch Großkommentar, vol 4 (4th edn, De Gruyter 2004) s 346, para 1; Ebenroth/Boujong/Joost/Handelsgesetzbuch (CH Beck 2001) s 346, para 1; Baumbach/Hopt/ Handelsgesetzbuch (31st edn, CH Beck 2003) s 346, para 1.

79 Handelsgesetzbuch Großkommentar (n 78) para 3. 
implied term approach; however, this may differ depending on the applicable legal system. ${ }^{80}$

To be bound by trade usage under a commercial contract, a continued or extended and recognized uniform practice is required. ${ }^{81}$ In this regard, though, a distinction must be made between trade usage (Handelsbrauch) and customary law (Gewohnheitsrecht). Although both have their origins in a continued or extended and recognized uniform practice, Handelsbrauch merely requires that a uniform practice should be followed with such regularity that it would create the expectation that it will be followed by others in the trade as a binding rule, ${ }^{82}$ while Gewohnheitsrecht also requires the universal observation of such practice together with a widespread conviction or recognition that such a custom constitutes a binding rule of law ${ }^{83}$ (the so-called opinio necessitatis). ${ }^{84}$ Customary law has the force of law, while trade usage is not enforceable per se and is limited to a particular trade or industry.

\section{Mixed law}

In South African law, custom will qualify as a source of law if it had been in use for a long time, is reasonable, certain in content, well known, and followed by the community. ${ }^{85}$ The Appellate Court ruled that substantially there is no difference between English law and Roman Dutch law regarding the existence of a custom. The only real difference is that Roman Dutch law is satisfied if the custom is simply old, while English law requires an immemorial origin. ${ }^{86}$ Although the traditional distinction between custom and trade usage recognized by English law was at first followed by South African courts, ${ }^{87}$ it was later rejected on the

80 Basedow (n 3) 706-7. See also Handelsgesetzbuch Großkommentar (n 78) para 4 and Baumbach/ Hopt/Handelsgesetzbuch ( $\mathrm{n} 78$ ) para 8 , which note that trade usage operates on the basis of ergänzende Auslegung of the contract and, thus, as implied term. See, however, Schwenzer, Hachem and Kee, (n 10) para 27.30, who refers to the quasi-statutory nature of Dutch law. Dutch Commercial Code arts $6.214,6.215$ provides that any contract concluded between parties in the course of their business will be subject to standard rules of the industry or trade where those rules have been acknowledged by a commission established by the Ministry of Justice. See also the discussion of art 6:248 lid 1 Dutch Civil Code in $M r C$ Assers Handleiding tot de beoefening van het Nederlands Burgerlijk Recht, vol 7 (8th edn, Kluwer 2013) part 1, paras 25-6, which recognizes the objective operation of usage even in the absence of knowledge, but which questions an implied term approach unless it can be justified on the basis of good faith or where it applies as custom.

81 Nigel Foster, German Legal System and Laws (2nd edn, Blackstone Press 1996) 58-60.

82 RGZ 110, 47 requires 'durchgehende Zustimmung und Rechtsüberzeugung der beteiligten Kreise sowie einen angemessenen Zeitraum der Übung.'

83 BVerfGE 57, 134; BGHZ 40, 26. See also Foster (n 81) 59-60.

84 Andreas W Renck, 'Der Einfluß der INCOTERMS 1990 auf das UN-Kaufrecht: Eine Untersuchung zu den rechtlichen Wirkungen der INCOTERMS 1990 im Recht des internationalen Warenkaufs' (LLM thesis, University of Hamburg, 1995) 20, 22; Dilshad Said, 'Das Risiko der Erteilung von Exportgenehmigungen nach den INCOTERMS, verglichen mit dem BGB’ (LLD dissertation, University of Trier, 1993) 31-2.

85 Van Breda v Jacobs 1921 AD 330. South African Constitution 2006 s 231(4) also recognizes the force of customary law, irrespective of whether it is local or international customary law.

86 Van Breda (n 85).

87 Crookv Pedersen 1927 WLD 62; Frank v Ohlsson's Cape Breweries Ltd 1924 AD 289, 295; Coutts v Jacobs 1927 EDL 120, 128. 
grounds that it was not part of Roman Dutch law. ${ }^{88}$ It, therefore, appears that no distinction is made any longer. ${ }^{89}$

For a trade usage to be implied, the usage should be universally and uniformly observed within the particular trade concerned, long established, notorious, reasonable, and certain and should not be in conflict with the positive law or with the provisions of the contract. ${ }^{90}$ Actual knowledge of the usage is not required in order for a party to be bound. All that is required is that the usage must have 'acquired such notoriety within the branch of trade or commerce... that any person in that branch... who enters into a contract of a nature affected by [the] usage, must be taken to have done so with the intention that the usage should form part of the contract.'91

In South African law, however, the notion of 'implied terms' can refer to a variety of concepts. ${ }^{92}$ Apart from the unexpressed or tacit agreement of the parties that may be derived from the surrounding circumstances, ${ }^{93}$ it can also refer to instances where the term is implied by operation of law independent of party agreement as a so-called naturale of the contract. Terms implied by law can be derived from the common law, statute, and also from trade usage or custom as long as they are not in conflict with the express provisions of the contract. ${ }^{94}$

Scholars, however, differ on the role that usage fulfils in South African law. According to Richard Christie and Graham Bradfield, trade usage occupies 'an intermediate position between terms implied by law and tacit terms'. ${ }^{95}$ They believe that, as is the case in English law, custom and usage should be distinguished. If a trade usage is known to both parties, it can be presumed that both

88

9

Coutts (n 87); Catering Equipment Centre v Friesland Hotel 19674 SA 336 (O); Tolgaz Southern Africa $v$ Solgas (Pty) Ltd 20094 SA 37 (W).

Tropic Plastic and Packaging Industry v Standard Bank of SA Ltd 19694 SA 108 (D); Barclays Bank International Ltd v Smallman 1977 1 SA 401 (R); Catering Equipment (n 88); Tolgaz (n 88). Contra RH Christie and GB Bradfield, Christie's: The Law of Contract in South Africa (6th edn, Lexis Nexis 2011) 170, who are still in favour of such a distinction for the reason that custom may be against the positive law, while trade usage may not.

90 Crook (n 87) 71; Golden Cape Fruits (Pty) Ltd v Fotoplate (Pty) Ltd 19732 SA 642, 645 (C).

91 Coutts (n 87) 133-4.

92 In a dissenting judgement, in Alfred McAlpine \& Son (Pty) Ltd $v$ Transvaal Provincial Administration 19743 SA 506 (A) 531-2, Corbett AJA speaks of the ambiguous nature of the expression 'implied term'. Due to the influence of English law on South African law, 'implied terms' and 'tacit terms' are often used interchangeably when referring to the incidentalia of a contract, but it can also refer to terms implied by law.

93 Alfred McAlpine (n 92) 532-3 (A); Botha v Coopers \& Lybrand 20025 SA 347, 360D-F (SCA). Such an inferred intention is based on the business efficacy of the contract. See also South African Forestry Co Ltd v York Timbers Ltd 20053 SA 323, 339E (SCA); Wilkens v Voges 19943 SA 130 (A).

94 Alfred McAlpine (n 92) 531 (A); Crook (n 87); Coutts (n 87); Catering Equipment (n 88); Golden Cape Fruits (n 90); Barclays Bank (n 89). According to Schalk van der Merwe, LF van Huyssteen, MFB Reynecke and GF Lubbe, Contract General Principles (4th edn, Juta 2012) 241-2, 246, trade usage may function as a naturale of the contract and, thus, a term implied by law. Such usage applies independent of whether the parties are aware of the usage or not. However, where knowledge is required for its operation, it may only apply as a tacit term. Policy considerations would ultimately determine when usages are to operate as terms implied by law and when as tacit terms. See also Bredenkamp \& ors $v$ Standard Bank of SA Ltd 20104 SA 468 (SCA) 473 for the difference between tacit terms and terms implied by law.

95 
would intended it to become part of their agreement, and, thus, it will be incorporated as a contractual term based on their tacit agreement. Even where one of them had no knowledge of such usage but he conducted himself in such a manner that knowledge could be assumed, the usage would still be incorporated into the contract on the basis of quasi mutual assent. A party would therefore be bound by the reliance that his conduct created. According to Christie and Bradfield, when they imply a term by law, the courts often blur the issue by not properly inquiring into the conduct of the party professing ignorance of a usage. It is their opinion that trade usage should only be implied by law when it has developed into a rule of law that the court can take judicial notice of. ${ }^{96}$ Alastair Kerr, on the other hand, rejects the notion of a distinct 'intermediate' category. He distinguishes between implied (tacit) terms and residual terms. According to him, the requirements of notoriety, reasonableness and time, which trade usages have to meet, will differ depending on whether the usage is incorporated into the contract as an implied term or whether it is imposed by law as a residual term. The requirements for residual terms would be more stringently applied as any person dealing in that particular branch of the trade would be presumed to have knowledge of the trade usage even in the absence of real knowledge. ${ }^{97}$

\section{Summary of findings}

The analysis has shown that, for trade usage to apply, national law does not require actual knowledge and that constructive knowledge will suffice. Where the legal systems differ is the degree or level of constructive knowledge and, thus, whether trade usage can apply on the basis of implied or presumed intention. Implied intention would exist where both parties have knowledge of the usage but have not explicitly agreed that the usage should apply-the so-called 'subjective approach'. On the other hand, constructive knowledge derived from regular observance of the usage in the trade or industry could give rise to a presumption of intention, even where one of the parties to the contract would be ignorant of the usage. In these cases, knowledge is assigned in order to protect the expectations of the other party to the contract based on the fact that you engage in a trade where such usage is well known and regularly observed. This is commonly referred to as the objective approach. However, knowledge is sometimes assigned in circumstances where it would be hard to imagine that the parties intended to contract on the basis of such a usage. Where one of them was unaware of the usage and had no prior experience in that trade, and it is clear that, were the usage known to both, they would have contracted out or, where the usage is against the express terms and spirit of the contract, knowledge of the usage and the intention to contract on that basis would be imputed purely on grounds of

96 Ibid. See also AJ Kerr, 'To Which Category of Provisions of a Contract Do Provisions Originating in Trade Usage Belong? Problems in Regard to Quasi-Mutual Assent' (1996) 59 Tydskrif vir Hedendaags Romeins-Hollandse Reg 331, 332 for criticism against this construction.

97 AJ Kerr, The Principles of The Law of Contract (6th edn, Butterworths 2002) 380-1; Kerr (n 96) 331-3. See also AJ Kerr, 'Trade Usage and Custom' (1970) South African Law Journal 403, 405-7. 
protecting the expectation of the other party or other policy considerations and not on implied intention. In these cases, there is a fine line between applying trade usage on the basis of presumed or imputed intention and instances where trade usage is imposed by law independent from party intent. Some domestic systems might have crossed that line already in that the courts apply trade usage under the disguise of an objective approach to contract interpretation while in actual fact they are merely applying trade usage as a source of law.

In South African law, trade usage can function as terms implied by law if they meet certain criteria. South African scholars, however, seem to be divided on the legal nature of usage. As a result of its historic ties with English law, some scholars still support the English law approach that distinguishes custom from usage and where usage is afforded legal force as an implied term of the contract. However, it would seem that trade usage can be incorporated by law if it meets certain stringent criteria. In American law, similar to the position in South African law, the traditional distinction between custom and usage has faded. However, scholarly opinion shows that the courts tend to blur the line between constructive knowledge and normative law that is recognized by the UCC by still relying on presumed knowledge in circumstances where both parties regularly engage in the trade. Civil law systems seem to prefer the implied term approach based on constructive knowledge derived from the circumstances of the trade. However, there are instances where intention is imputed to the parties in situations where they might be unaware of the usage, which may actually border on a normative approach. In other instances, statutory law confers trade usage with normative status by applying government-sanctioned rules of the trade or industry. In the latter case, trade usage obtains its normative force from the law itself as statutory trade usage.

\section{International law}

\section{A. CISG}

Within the framework of the CISG, usage plays an important role in interpreting the terms of a contract in the context of both its formation and performance. ${ }^{98}$ The CISG only mentions trade usage and practice; no reference is made to custom as such. ${ }^{99}$ Although no definition is provided, commentators warn that international trade usages should be treated as an autonomous concept and not with reference to any 'preconceived domestic notions'. ${ }^{100}$

98

99 MJ Bonell, 'Article 9' in CM Bianca and MJ Bonell, Commentary on the International Sales Law: The 1980 Vienna Sales Convention (Giuffrè 1987) para 3.2, points out that the Convention has chosen to refer to 'usages' in the widest sense of the word and not to distinguish between customs, usages, Handelsbräuche, and Gewohnheitsrecht as national laws do.

100 Martin Schmidt-Kessel, 'Article 9' in Ingeborg Schwenzer (ed), Schlechtriem and Schwenzer Commentary on the UN Convention on the International Sale of Goods (CISG) (3rd edn, OUP 2010) para 11; Pamboukis (n 8) 111. See also the interpretation guidelines provided in CISG (n 9) art $7(1)$. 
The requirements stated by Article 9, paragraphs 1 and 2, shed some light on the distinction between trade practices and usages. Paragraph 1 provides for practices established by the parties. For a practice to be established, the case law requires a long-lasting contractual relationship that involves a number of sale agreements ${ }^{101}$ with such frequency that they create a common basis for understanding their future conduct in similar circumstances. ${ }^{102}$ Paragraph 1 also refers to trade usages to which the parties have agreed. ${ }^{103}$ To determine the content of such agreement, guidance can be sought in Article 8 to establish the intention of the parties, whether express or implied. ${ }^{104}$

In contrast to the purely subjective approach of paragraph 1, paragraph 2 reconciles the subjective and objective approaches. ${ }^{105}$ Usages 'of which the parties knew $^{106}$ or ought to have known ${ }^{107}$ and which in international trade is widely known to, and regularly observed by, parties to contracts of the type involved in the particular trade concerned' will apply to the contract, unless the parties have agreed otherwise. Paragraph 2, thus, requires actual or constructive knowledge. ${ }^{108}$ In the latter case, contract interpretation and supplementation take place independent of the actual intent of the parties by conferring legal effect on an objective expectation. ${ }^{109}$ Paragraph 2 requires that the trade usage should be widely known, and it must be regularly observed in a particular trade over a geographically large area to the extent that merchants in that trade are expected to have knowledge of such usage. Actual knowledge is, thus, not a requirement for the operation of trade usage under the CISG as long as the usage is internationally well known and regularly observed in the trade or industry to which it applies. It is neither required that knowledge of the usage should be universal nor that the usage should be observed universally or in all trades. Knowledge should, however, be universal in the trade or industry in which the trade usage applies. A purely domestic usage will suffice as long as it is widely known in the particular trade or industry and is regularly applied in international transactions of that nature. ${ }^{110}$

CLOUT Case No 217 (Handelsgericht Aargau, Switzerland, 26 September 1997); CLOUT Case No 221 (Zivilgericht des Kantons Basel-Stadt, Switzerland, 2 December 1997); CLOUT Case No 360 (Amtsgericht Duisberg, Germany, 13 April 2000); Landgericht Zwickau, Germany, 19 March 1999 <http://cisgw3.law.pace.edu/cases/990319g1.html> accessed 11 April 2015.

102 Schmidt-Kessel (n 98) para 8; Honnold (n 9) para 116.

103 For example, an agreement to contract on the basis of Incoterms.

104 Schmidt-Kessel (n 100) paras 6-7.

105 Pamboukis (n 8) 108-9.

106 This phrase introduces the so-called 'subjective' theory whereby usages will only apply if the parties have agreed to them. Usages unknown to either of the parties will not bind them.

107 This phrase introduces the objective theory. Instead of a reasonableness criterion, which was required by its predecessor ULIS, CISG (n 9) art 9(2) uses an objective standard of knowledge that protects contractual expectations even if one of them would not be aware of the usage.

108 Schmidt-Kessel (n 100) para 19.

109 Ibid paras 1, 12; Honnold (n 10) para 121. See also Bonell (n 99) para 2.2.1.

110 Schmidt-Kessel ( $\mathrm{n} 98$ ) paras 16, 18. This does not mean that the usage should be an international usage. Domestic usages will suffice if they are universally known and observed. See also Bonell ( $\mathrm{n}$ 97) paras 2.2.2-3; Honnold (n 9) para 120.1. 
Some commentators argue that the requirements of Article 9(2) are premised on a presumption of implied intention. ${ }^{111}$ However, where one or both of the parties to the contract have no knowledge of the usage but ought to have known it, the question has to be asked whether it is the law itself, rather than the implied agreement of the parties, that confers binding force on the usage? Whether the CISG attributes a normative function independent of party agreement to trade usages is controversial. Some scholars support such a view, ${ }^{112}$ while others argue that in the scheme of the Convention trade usage can only function as a gapfiller to supplement the intention of the parties where they failed to make alternative arrangements. The applicable usage then 'has the same effect as a contract' between the parties ${ }^{113}$ and 'only establishes terms implied by usage. ${ }^{\text {,14 }}$ Supporters of the latter view, however, recognize that by virtue of Article 9(2) the parties to an international sales contract may be bound by a trade usage even in the absence of actual intent. According to this view, paragraph 2 requires both a subjective element, namely that the parties knew or ought to have known the trade usage as well as an objective element that the usage should be well known and regularly observed in international trade in that specific type of trade. It is their view that the provision confers legal effect on the objective expectations of the parties and, thus, is based on a hypothetical intention in line with Article $8(2)$, which is to be distinguished from fictional intention. $^{115}$

However, an American Federal District Court held that 'the usages and practices of the parties or the industry are automatically incorporated into any agreement governed by the Convention, unless expressly excluded by the parties.' 116 The Court construed Article 9(2) of the CISG without requiring knowledge, actual or presumed. This seems to border on a normative approach independent of party agreement. The prevailing opinion, however, still appears to be that trade usage fills contractual gaps on the basis of presumed intention as an implied term and does not function by operation of law per se.

111 Pamboukis (n 8) 118-9; Schmidt-Kessel (n 98) paras 2, 12; Schwenzer, Hachem and Kee (n 9) para 27.40 .

112 Pamboukis (n 8) 119. He finds support for his view in Bonell (n 97) para 2.2.1, who is of the opinion that the proviso to Art 9(2), namely that trade usage can be supplanted by agreement, would only make sense if usage is to operate as a rule of law. Consequently, any implied agreement on trade usage would merely amount to a legal fiction. See also Patrick X Bout, 'Trade Usages: Article 9 of the Convention on Contracts for the International Sale of Goods (1998)' text accompanying n 23 <http://www.cisg.law.pace.edu/cisg/biblio/bout.html> accessed 8 April 2015; Pilar Perales Viscasillas, 'Comments on the draft Digest relating to Articles 14-24 and 66-70' in Franco Ferrari et al (eds), The Draft UNCITRAL Digest and Beyond: Cases, Analysis and Unresolved Issues in the UN Sales Convention (Sweet \& Maxwell, London 2004) 259, 290.

113 Honnold (n 9) para 122.

114 Schmidt-Kessel (n 98) para 2, Bonell (n 97) para 2.2.1.

115 Schmidt-Kessel (n 98) paras 1, 12. See also Honnold (n 9) para 120.1; Bonell (n 99) para 2.2.1.

116 CLOUT Case No 579 (Geneva Pharmaceuticals Tech Corp v Barr Labs Inc, Federal District Court New York, USA, 10 May 2002). 


\section{B. Principles of International Commercial Contracts}

Article 1.9 of the International Institute for the Unification of Private Law's (Unidroit) Principles of International Commercial Contracts (PICC) is to a large extent similar to Article 9 of the CISG. ${ }^{117}$ Once again, the concept of trade usage is not defined. Paragraph 1 is identical to Article 9(1) of the CISG. Paragraph 2 contains some differences. The major difference is that UNIDroIT's PICC do not distinguish between actual or attributed knowledge of the usage as the CISG does. It does not even require knowledge of the usage at all. It merely states that the parties 'are bound by a usage that is widely known to and regularly observed in international trade by parties in the particular trade concerned'. It would seem that the wording supports a more objective approach than that of the CISG, which, at the very least, requires constructive knowledge of the usage. An additional requirement, also with no equivalent in the CISG, is that application of the trade usage should not be unreasonable in the circumstances. Although reasonableness per se is not a requirement, a usage may be conceived as unreasonable in certain circumstances and would, therefore, not apply, while that very same usage may be reasonable in other circumstances. ${ }^{118}$ Trade usage will also prevail over conflicting provisions of the Principles.

Although this provision displays an objective approach where parties will be bound to the usage even in the absence of knowledge, ${ }^{119}$ Comment 6 to the provision states that, once these conditions are met, a usage will bind the parties as an implied term of the contract, and it will only be superseded by the express agreement of the parties and by mandatory law. Since trade usage still functions as an implied term, it is not entirely clear whether some form of agreement will be imputed to the parties or whether it will function as terms implied by law. If a usage is widely known in a particular trade, the parties can be presumed to have knowledge of the usage and, thus, also to have implicitly agreed to the usage as a contract term.

\section{Principles of European Contract Law}

Article 1:105 of the Principles of European Contract Law (PECL) itself does not define 'usage' and 'practice'. ${ }^{120}$ The Commentary to the article, however, provides some clarification. Usage is defined as 'a course of dealing or line of conduct which is and for a certain period of time has been gradually adopted by those engaged in trade or a particular trade. ${ }^{121}$ Parties will be bound by any usage 'which would be considered applicable to persons in the same situation as the parties', provided that the usage is not unreasonable and that it is consistent with

117 UNIDROIT Principles of International Commercial Contracts (UNIDroIT 2010) [PICC].

118 Ibid art 1.9, comment 5 .

119 See also Schwenzer, Hachem and Kee (n 10) paras 27-41. Cf PICC (n 117) art 5.1.

120 Ole Lando and Hugh Beale (eds), Principles of European Contract Law, parts 1 and 2 (Kluwer Law International 2003) [PECL].

121 Ibid art 1:105, comment A. 
the express terms of the agreement. ${ }^{122}$ There is no requirement of knowledge, whether express or constructive. The Commentary further clarifies that the parties will be bound by usages of the trade even in the absence of agreement or knowledge. ${ }^{123}$ All that is required is that such usage should be considered applicable by similar parties in that particular trade. Comment $\mathrm{E}(1)$ explains that the usage must be well established and must be generally observed in the particular trade so that traders who engage in that trade will consider it to be applicable to their contract. The usage is not restricted to international usages but could include local and national usages as long as the usage usually binds parties engaged in international trade. Application of the usage should also be reasonable. Comment $\mathrm{B}(2)$ clarifies that regular observance of a usage would create the inference that the application of the usage is reasonable but that it would in the final instance be judged in the context of the particular circumstances in which it is to be applied.

According to the commentators, the PECL provides a truly objective approach, ${ }^{124}$ which will supersede all rules that would otherwise apply. ${ }^{125}$ It would seem that the PECL does not base the operation of trade usage on an implied term approach. Thus, usage enjoys normative value totally independent of party intent, whether actual or imputed. ${ }^{126}$

\section{Draft Common Frame of Reference}

Book 2 of the European Draft Common Frame of Reference (DCFR) provides for trade usages in Article II-1:104. Parties will be bound to usages that they have agreed on or to any practices that they have established between themselves and by 'a usage which would be considered generally applicable to persons in the same situation as the parties, except where the application of such usage would be unreasonable. ${ }^{127}$ Again, no definition is provided by the text itself, but Comment A to the provision describes usage as 'a course of dealing or line of conduct which is, and for a certain period of time has been, generally adopted by those engaged in a trade or other activity.' On the other hand, a practice will be considered as being established between the parties where there is 'a sequence of previous conduct in relation to a particular transaction or a particular kind of transaction between the parties', which could be regarded as a common understanding. ${ }^{128}$ It is not required that the usage be well known and regularly observed

122 Ibid art 1.105(2).

123 Ibid art 1.105, comments A and E.

124 Anja Carlsen, 'Remarks on the Manner in Which the PECL May Be Used to Interpret or Supplement Article 9 CISG' < http://cisgw3.law.pace.edu/cisg/text/anno-art-09.html> accessed 11 April 2015.

125 PECL (n 120) art 1.105, comment B.

126 Ibid art 1.105, nn 4 (a) and (b) to the comments.

127 Christian Von Bar, Eric M Clive, Hans Schulte-Nölke and HG Beale (eds), Principles, Definitions and Model Rules of European Private Law: Draft Common Frame of Reference (Sellier European Law Publishers 2008) art II-1:104 [DCFR].

128 Ibid art II - 1:104, comment A. 
in international trade but, simply, that it must be 'considered generally applicable' in that particular trade or industry. The wording is similar to that of Article 1:105 of the PECL. However, one would expect that usages that are 'generally applicable' would also be well known, generally observed as well as reasonable and consistent with the express terms of the agreement. Usage is not limited to international usages but may also include local usages if that would be reasonable to bind both parties to such a usage. ${ }^{129}$ Paragraph 3, furthermore, extends this rule to other unilateral juridical acts such as offer and acceptance. ${ }^{130}$ The explicit reference to the role of usage in contract formation clarifies an issue that might otherwise not have been certain.

Scholars have held that the DCFR does not restrict usage to an interpretive or gap-filling role but that it introduces usage 'as a binding, objective standard rather than as a supplementary device'. ${ }^{131}$ This view is supported by the Commentary to the Rules, which states that agreement on the usage is not a requirement for its operation $^{132}$ and that usage functions independently of will as 'legal norms'. ${ }^{133}$ Hence, this provision goes one step further than merely giving effect to usage on the basis of good faith and the objective expectations of the parties. This approach could thus be construed as conferring objective normative authority to trade usage so that it functions as autonomous law in so far as it does not violate any mandatory law.

\section{E. Common European Sales Law}

The proposal for a Common European Sales Law (CESL) has been withdrawn pending deliberations on a new format in order to address the problems related to consumer cross-border transactions that are concluded electronically. For academic purposes, however, it would be relevant to note how it proposed to deal with trade usage in general. Article 67 of the CESL states that, in the context of business-to-business contracts between traders, ${ }^{134}$ 'the parties are bound by any usage which they have agreed should be applicable and by any practice they have established between themselves' as well as by 'a usage which would be considered generally applicable by traders in the same situation as the parties', unless the parties have agreed otherwise or if the usage is in conflict with the mandatory law of the CESL. This provision is modelled on that of the PECL and the DCFR. In the

129 Ibid art II - 1:104, comment E.

130 Ibid art II - 1:104, comment F.

131 Anne-Katherin Drettmann, 'Would English Law on Trade Usages Benefit from Adopting a More Formal Approach such as Seen in Other Jurisdictions as Well as in International Conventions?' (thesis, University of West-of-England, 2009) s C, para VIII, subpara $3<$ http://www.cisg.law. pace.edu/cisg/biblio/drettmann.html> accessed 11 April 2015. See also Horst Eidenmüller and others, 'The Common Frame of Reference for European Private Law: Policy Choices and Codification Problems' (2008) 28 Oxford Journal of Legal Studies 659, 680.

132 DCFR (n 127) art II - 1:104, comment E.

133 Ibid art II - 1:104, n 16 to the comments.

134 The operation of trade usages and practices is limited to traders and will not be applied in the context of consumers. See Eva-Maria Kienenger, 'Article 67' in Reiner Schulze (ed), Common European Sales Law (CESL): Commentary (CH Beck-Hart 2012) para 12. 
absence of any clear definition, ${ }^{135}$ the Commentary defines usage as 'general trade lines of conduct' and practice as 'a common understanding on conduct by the parties. ${ }^{136}$ However, these terms are consistently used as a joint phrase that might indicate that there is not much of a difference in meaning. ${ }^{137}$ Once again, there is no requirement of specific knowledge of the trade usage, but an objective test is used, namely that the usage should be generally applicable in the trade in which the parties are doing business. This test would imply that the usage has to be well known and regularly observed in the trade concerned. 'Usage' is not restricted to international usages as long as the parties are expected to adhere to a national or local usage. ${ }^{138}$ Although it is not required that the usage should be reasonable, the Commentary clarifies that this would be implied since an unreasonable usage would usually not be considered 'generally applicable'. ${ }^{139}$ Party autonomy also enjoys priority over trade usage. ${ }^{140}$

Article 67 would, therefore, confer autonomous normative power on usage. ${ }^{141}$ However, although the Commentary confirms that the usage would be binding on the parties in the absence of party agreement, ${ }^{142}$ it states at the same time that the provision would mostly apply in circumstances where the parties are expected to know and adhere to the usage, which are the same circumstances where constructive knowledge and tacit agreement would be implied. ${ }^{143}$

\section{F. Summary of findings}

The CISG, in Article 9(2), attempts to reach a compromise between the subjective and objective approaches. Subsequent instruments of harmonization, which aim to provide a common set of principles or rules, focus solely on an objective approach. The PICC, PECL, DCFR, and CESL move beyond constructive knowledge by keeping the parties bound to trade usages that are widely known or generally applicable by parties in the particular trade concerned. No mention is made that they 'ought to have' knowledge of the trade usage. Thus, trade usage is elevated to a level where contract terms are implied independently of party intent or agreement. However, whether, in practice, trade usage will be implied by law or as a contractual term is not always clear since the circumstances where trade usage

135 Ibid para 10.

136 Ibid para 5.

137 Ibid para 10.

138 Ibid para 8.

139 Ibid paras 2, 7-8. See, however, para 11 where she criticizes the article's general formulation, which may give rise to problems of interpretation.

140 Ibid paras 4, 9.

141 Kienenger ( $n$ 134) para 4 states that the CESL 'view party practices as a source of contract terms in their own right'. This contention is supported by the fact that art 68 specifically provides for implied terms as a separate category, which according to the hierarchy of the CESL ranks after trade usage, but usage will naturally influence the determination of implied terms. Trade usages and practices as referred to in art 67 would, therefore, not amount to implied terms.

142 Ibid para 7.

143 Ibid para 8. 
finds application by law will often be similar to those where constructive knowledge would be presumed.

\section{Conclusion}

Trade practices and usages are widely and regularly followed in international trade and, therefore, are presumed to be economically efficient as inefficient practices would not have stood the test of time. ${ }^{144}$ All in all, transaction costs are reduced and the economic efficiency of the transaction increased. Moreover, trade usage is not only cost efficient in regard to a reduction in transaction costs, it also displays efficiency through its specific focus on the needs of the trade and its flexible and dynamic character. Trade usage has the ability to evolve as trade conditions develop, which is an advantage if compared to the static nature of domestic law and international conventions in particular. ${ }^{145}$

The dynamic nature of usage, however, has its negative side. Although one would assume that the content of usages is certain and clear, otherwise they would not have become widely established and internationally known, the fact that they develop and change over time is a challenge for legal certainty. Unwritten and uncodified practice is inherently uncertain, which makes it difficult to invoke it satisfactorily. It is not very easy to establish and prove a trade usage, as expert witnesses are often in dispute on its content. ${ }^{146}$ However, the efficiency of trade usage has to be weighed against the risk of legal uncertainty and the costs that it will entail. ${ }^{147}$ Contractual risks are normally allocated on the basis of presumed knowledge. In the absence of any explicit agreement on the applicable law, it is to be assumed that both parties know the governing law of the contract and their respective rights and obligations under that law, otherwise they would have taken the time and effort to negotiate specific contractual terms as well as a choice of law. In the international context, where at least one of the parties to the contract will be faced with a foreign legal system, the risk of legal uncertainty that accompanies these situations would be no different from that which applies to trade usage. By conferring a normative quality and function to usage, the expectations of parties that have knowledge of such usage are protected

144 Dalhuisen (n 27) 159; Dalhuisen (n 3) 370.

145 Cf UCC (n 31) s 1-103(b), which provides for the liberal interpretation of the Code in line with its underlying purposes and policies, namely to permit the continued expansion of commercial practices and to supplement the provisions of the Code with the law merchant.

146 See eg the problems incurred with expert witnesses in Libyan Arab Foreign Bank $v$ Bankers Trust 1989 QB 728.

147 Dalhuisen (n 27) 34 is of the opinion that professional business people are in a position to handle the risks of uncertainty which comes as a cost in exchange for the benefits derived from the flexible and dynamic nature of custom. For the debate on the value and costs of incorporating custom, see, in general, Clayton P Gillette, 'The Law Merchant in the Modern Age: Institutional Design and International Usages under the CISG' (2004) 5 Chicago Journal of International Law 157; Avery Wiener Katz, 'The Relative Costs of Incorporating Trade Usage into Domestic versus International Sales Contracts: Comments on Clayton Gillette, Institutional Design and International Usages under the CISG' (2004) 5 Chicago Journal of International Law 181, and, more recently, Bernstein, 'Trade Usage' and 'Merchant Law' (n 2). 
as they would anticipate compliance by their counterparties. ${ }^{148}$ If they do not want the usage to apply to their contract, they are free to contract out of the usage.

The premise of this article is that trade usages constitute practices that have developed among merchants in a particular trade and that they follow out of some sense of obligation. To that extent, trade usage presents as a form of self-regulation. By observing their own distinct customary ways of doing business, merchants engage in a form of private rule-making that binds the parties to a contract in the same way as any legal rule would do. Courts and tribunals merely declare their legal force but are not the source of their existence. Trade usage is law made by merchants for merchants, which will precede the default law of the contract and will only be trumped by party agreement and the mandatory law of the contract. Many rules of the commercial law we know today have originated in a course of dealing or practice that existed between individual parties, later developed into a trade usage and from there into law, ${ }^{149}$ alternatively represent international practices. ${ }^{150}$

The analysis undertaken in this article has shown that, apart from some exceptions, domestic law mostly relegates trade usage to a gap-filler or interpretive tool that finds application as an implied term of the contract based on actual or presumed agreement. One commentator has remarked that the implied term approach towards trade usage is effectively a 'watering down' of the lex mercatoria, which was applied as autonomous law from the sixteenth to the nineteenth centuries. ${ }^{151}$ Although it is not in dispute that trade usage is routinely implied by courts of law and arbitral tribunals, this article has asked whether courts only fill contractual gaps by means of constructive hypothetical intent or whether the label of constructive knowledge sometimes merely disguises the fact that trade usage is imposed by courts as law to achieve an economically viable and reasonable result. Courts that impute intentions to parties where there is no real evidence that they had intended for a usage to apply might in actual fact be conferring trade usage with autonomous normative quality. It is well known that commercial arbitrators are more favourable towards custom and trade usage and the lex mercatoria in general and that, in the context of international sales, they would be more inclined to confer trade usage with autonomous normative force than national courts of law would. ${ }^{152}$

Gillette (n 7) 708; Warren (n 2) 518. See also Warren's argument in regard to newcomers to the trade (at 546-7).

149 Schmitthoff (n 3) paras 4-6; Alejandro M Garro, 'Rule-Setting by Private Organisations' in Ian Fletcher, Loukas Mistelis and Marise Cremona (eds), Foundations and Perspectives of International Trade Law (Sweet and Maxwell 2001) 310, paras 22-012-4. Custom, however, does not play an insignificant role in national law. Common law legal systems are largely based on custom. Even statutory law is often mere codifications of customary law. See Braybrooke (n 64) 73, 86; Dalhuisen (n 27) 157.

150 Goode (n 27) 5-6.

151 Wethmar-Lemmer (n 19) 190.

152 On the practice among international commercial arbitrators to resort to a so-called 'new law merchant', which consists of internationally accepted principles of international trade based on mercantile customs and usages, see in general Larry A DiMatteo, 'Soft Law and the Principle of 
The analysis of uniform law projects has yielded a similar conclusion. The CISG bases the operation of trade usage on actual agreement or on implied consent that is derived by means of an objective approach based on constructive intent. Uniform law projects such as the PICC, the PECL, the DCFR, and the CESL base the operation of trade usage on a truly objective approach where knowledge, actual or constructive, is not even a requirement. It would seem that these uniform law instruments bestow normative value on trade usage once it is well established and regularly observed in a particular trade or industry.

The difference in applying trade usage according to an objective interpretive approach or as autonomous law appears to be slight. ${ }^{153}$ Whether the international instruments per se represent international autonomous law based on international customs and usages (a so-called new lex mercatoria) is outside the scope of this article. ${ }^{154}$ However, what is clear is that trade usages operate both in national and international law irrespective of the parties' awareness. Moreover, international codifications of trade usages and practices, such as the Incoterms rules and the UCP, are increasingly treated as international usage that is automatically implied into a contract even in the absence of express reference. ${ }^{155}$ Whether these international instruments of standardization would be implied as autonomous law or merely as implied terms would in the final instance depend on whether they meet the stringent requirements for notoriety and observance within the trade or industry and whether the mercantile community feels obliged to observe the standard rule as mercantile custom. What is clear, though, is that standardized trade usage that parties agree on, standard term contracts, or trade usage that is incorporated into national statutes and international conventions reduce the need for a resort to unwritten international usages and facilitate legal certainty.

As for unwritten international trade usage, whether they are implied on the basis of an objectively derived intention by virtue of reasonable expectations, constructive knowledge and good faith, or whether trade usage functions as autonomous law independently of knowledge and implied agreement is a fine line

Fair and Equitable Decision Making in International Contract Arbitration' (2013) 1 China Journal of Comparative Law 1, 3-8; Berman and Kaufman (n 5) 276-7; Maniruzzaman (n 6) 706.

154 Some scholars, eg, argue that the PICC constitute a codification of the lex mercatoria. See Michaels (n 4) 457.

155 District Court, Southern District of Texas, United States, 7 February $2006<$ http://cisgw3.law. pace.edu/cases/060207u1.html> accessed 11 April 2015; CLOUT Case No 447 (US District Court, Southern District of New York, United States of America, 26 March 2002); CLOUT Case No 575 (US Court of Appeals (5th Circuit), United States, 11 June 2003); Juzgado Comercial No 26 Secretaria No 51, Argentina, April 2003 (Docket No 44766), English translation <http://cisgw3. law.pace.edu/cases/030400alhtml $>$ accessed 11 April 2015; Tribunal of International Commercial Arbitration at the Russian Federation Chamber of Commerce and Industry, Russian Federation, 6 June $2000<$ http://www.cisg.law.pace.edu/cisg/wais/db/cases2/000606r1. html > accessed 11 April 2015; Corte d'appello Genova, Italy, 24 March $1995<$ http://cisgw3.law. pace.edu/cases/090128s1.html > accessed 11 April 2015; Tribunal Cantonal du Valais, Switzerland, 28 January 2009 (English translation) < http://cisgw3.law.pace.edu/cases/090128s1. html> accessed 11 April 2015. 
that can easily become blurred in its application. It is generally recognized that custom can function as a source of law if it satisfies certain stringent criteria. Where the requirements for custom and usage overlap, which is often the case, it is obviously much easier to make out an argument for the autonomous normative function of usage.

Despite uncertainty on its legal nature and the problems encountered with proving its existence and content, it cannot be disputed that trade usage still plays a significant role in modern day international commerce. It is recognized as one of the general principles of international trade, and international uniform law projects place significant value on its application even where one or both of the contractual parties are unaware of its existence. Whether its operation is through autonomous law or extensive contract interpretation should perhaps not be the central issue. The emphasis should rather be placed on the value that trade usage as a universally recognized principle could add to international commercial contracts in increasing the economic efficiency of the transaction. Its application by courts and tribunals should therefore be supported. As a result of its flexible nature, trade usage will continue to function as a tool for developing international commerce and, hence, the law regulating it. 